\title{
Climatic suitability of Aedes albopictus in Europe referring to climate change projections: comparison of mechanistic and correlative niche modelling approaches
}

D Fischer (dominik.fischer@uni-bayeuth.de) ${ }^{1,2}$, S M Thomas ${ }^{1}$, M Neteler ${ }^{3}$, N B Tjaden ${ }^{1}$, C Beierkuhnlein ${ }^{1}$

1. Department of Biogeography, University of Bayreuth, Bayreuth, Germany

2. Technische Universität München (TUM), Munich, Germany (present affiliation)

3. Department of Biodiversity and Molecular Ecology, Research and Innovation Centre, Fondazione Edmund Mach, San Michele all'Adige (Trento), Italy

Citation style for this article:

Fischer D, Thomas SM, Neteler M, Tjaden NB, Beierkuhnlein C. Climatic suitability of Aedes albopictus in Europe referring to climate change projections: comparison of mechanistic and correlative niche modelling approaches . Euro Surveill. 2014;19(6):pii=20696. Available online: http://www.eurosurveillance.org/ ViewArticle.aspx?Articleld $=20696$

Article submitted on 16 November 2012 / published on 13 February 2014

The Asian tiger mosquito, Aedes albopictus, is capable of transmitting a broad range of viruses to humans. Since its introduction at the end of the 2oth century, it has become well established in large parts of southern Europe. As future expansion as a result of climate change can be expected, determining the current and projected future climatic suitability of this invasive mosquito in Europe is of interest. Several studies have tried to detect the potential habitats for this species, but differing data sources and modelling approaches must be considered when interpreting the findings. Here, various modelling methodologies are compared with special emphasis on model set-up and study design. Basic approaches and model algorithms for the projection of spatio-temporal trends within the 21st century differ substantially. Applied methods range from mechanistic models (e.g. overlay of climatic constraints based on geographic information systems or rather process-based approaches) to correlative niche models. We conclude that spatial characteristics such as introduction gateways and dispersal pathways need to be considered. Laboratory experiments addressing the climatic constraints of the mosquito are required for improved modelling results. However, the main source of uncertainty remains the insufficient knowledge about the species' ability to adapt to novel environments.

\section{Background}

In recent years, European awareness concerning the introduction and establishment of invasive mosquitoes has increased, most notably due to the incursion of the Asian tiger mosquito, Aedes albopictus - the most invasive disease vector globally $[1,2]$. This mosquito has spread from its original distribution area in southeast Asia [3] to all continents via shipping of goods [4]. After its initial introduction to Europe at the end of the 2oth century, $A$. albopictus became well established in southern Europe [2]. Recent observations hint towards a spread of this vector to the continental interior of
Europe [5]. This mosquito is capable of transmitting several viruses that are pathogenic to humans $[1,6]$. Most strikingly, $A$. albopictus was the vector that caused the first autochthonous transmission of chikungunya virus [7,8] and dengue virus [9-11] in the Mediterranean area. More recently, a dengue outbreak occurred in the autonomous region of Madeira, Portugal. In this case, A. aegypti, the yellow fever mosquito, acted as the vector [12].

Several studies have aimed to determine the climatic suitability of $A$. albopictus at the end of 2oth and the beginning 21st century [13-15], as well as the expected future tendencies in Europe [16-19]. Most recently, Caminade et al. [19] implemented three established modelling approaches $[14,16,20]$, making use of new observations, climate data and a report on model quality. However, a comparative methodological evaluation of the different approaches was still missing. Here, we provide a comprehensive comparison of studies assessing the climatic suitability of European regions for $A$. albopictus as a result of a rapidly changing climate during the 21st century. General information as well as limitations in study design and data quality is highlighted. Uncertainties related to climate change and insect vectors are identified. In so doing, we aim to provide guidance for future research.

\section{Review of distribution models for Aedes albopictus}

In order to assess knowledge about the responses of $A$. albopictus to climate change in Europe, we conducted a literature search, using the Thomson Reuters Web of Knowledge research portal (which includes the databases Web of Science, BIOSIS, Current Contents Connect, MEDLINE and Journal Citation Reports) as well as Google Scholar. Search terms were built from all possible combinations of the keywords 'Aedes albopictus', 'Stegomyia albopicta' or 'Asian tiger mosquito' in combination with 'climat* change', 'climat* warming' 
or 'global warming'. We considered only those research studies with a detailed analysis of methodological tasks and comparison of results, in which distribution modelling approaches were applied to European regions.

Our search identified six studies (up to November 2012) that aimed to determine the distribution of $A$. albopictus in Europe [14-19]. Methodological details and study design are described (Tables 1 and 2). Four of them analysed changing spatial patterns of $A$. albopictus in Europe by using climate change scenarios [16-19]. The studies with projections were used to derive general trends concerning the future development arising from a comparison of the resulting projections. In this review, we bring these specific studies for Europe into a wider context, as we account for the (methodological) development in the creation of risk maps of $A$. albopictus in order to understand the philosophy behind the work more intuitively.

Generally, two methodological approaches seem to be appropriate for the projection of climatic suitability of European habitats for $A$. albopictus: mechanistic models and correlative niche models. Mechanistic models do not require geographical occurrence data for species. They are either based on the construction of overlay functions for climatic constraints in geographic information system (GIS) environments or processbased models with mechanistic principles. The aim of such models is to simulate and project the response of an individual organism or a population by explicitly incorporating biological processes calibrated with observations on individuals in natural populations and controlled field or laboratory studies [21]. Thus, mechanistic models rely on the implicit assumption that the model structure and process formulations are correct [22].

A second, rather statistical approach is the use of correlative environmental niche models. Here, species presence and, in some approaches, also absence locations are related to environmental or climatic variables with the aim of determining the species-specific niche (synonymously used: 'envelope') that is defined by the parameter values - including the multivariate combinations - from the known occurrences. This niche can be interpolated or extrapolated to infer species' geographical distribution. Advanced modelling techniques offer novel opportunities for the determination of species changing spatial distribution patterns as a response to environmental and climatic changes [23]. The main issue with correlative models is their dependence on the amount, quality and relevance of the data used [22]. Commonly, niche-modelling algorithms require presence as well as absence records. However, some models make use of pseudo-absence data or even presence-only data, as in many cases, absence data are not available. The lack of absence data may also suggest that areas where the species is missing might be suitable, but the insect may simply not be present yet. Consequently, presence-only models are appropriate to handle most of the data for mobile and invasive insects in the course of climate impact research.

\section{Distribution models devoid of climate change projections}

Several studies identified the past or current climatic suitability for $A$. albopictus, based either on mechanistic $[13,14,20]$ or correlative $[15,16,24,25]$ distribution modelling approaches for specific regions or globally. Here, we highlight studies with relevance for Europe.

\section{Mechanistic approaches}

Kobayashi et al. identified a close connection with the annual and January mean temperature for the distribution of $A$. albopictus in northern Japan [20]. In addition, a period with daily temperature continuing above at least $11^{\circ} \mathrm{C}$ during summer months (more than 186 days per year) was observed and interpreted as a requirement for larval development.

The first GIS-based risk maps were developed by Mitchell [13] for the Mediterranean Basin. Expert knowledge on temperature, rainfall and humidity as well as the photoperiod was applied in order to frame climatic constraints. For the United Kingdom, Medlock et al. [14] used temperature and daylight thresholds to simulate life cycle dynamics via overlay functions in GIS. Furthermore, they created different scenarios by altering the diurnal length of the photoperiod. This was done to assess the ability of eggs to survive in winter and predict the hatching in spring and the subsequent production of diapausing eggs in autumn. Consequently, the potential responses to these alterations in mosquito life cycle can be determined. It should be noted that the scenarios of Medlock et al. [14] do not refer to scenarios announced in the special report on emissions scenarios (SRES) [26] from the Intergovernmental Panel on Climate Change (IPCC). In the technical report of the European Centre for Disease Prevention and Control (ECDC), Development of Aedes albopictus risk maps [16], the approach from Medlock [14] is adapted, but was expanded to cover Europe. In this ECDC report [16], two further modelling approaches were used: one further mechanistic and one correlative approach, which are described below.

\section{Correlative approaches}

Presence/absence models

Many niche modelling algorithms require both documented presence, as well as absence localities in order to build statistical relationships. In its report, ECDC deployed random forest models (based on regression trees) in order to estimate the current climatic suitability for A. albopictus in Europe [16]. In short, random forest is an ensemble classifier that consists of combined decision trees and gives the class that is the mode of the classes by individual trees as an output. Centroids (geometric centres) of the European municipalities 
TABLE 1

Studies addressing current and projected climatic suitability of Aedes albopictus in Europe

\begin{tabular}{|c|c|c|c|c|c|c|c|}
\hline Study & Region & Model & $\begin{array}{l}\text { Input data: climate/ } \\
\text { environmental }\end{array}$ & $\begin{array}{l}\text { Validation or data/ } \\
\text { model predictive power }\end{array}$ & $\begin{array}{l}\text { Climate projection or } \\
\text { climate model }\end{array}$ & Scenario & Time step \\
\hline $\begin{array}{l}\text { Medlock } \\
\text { et al. } 2006 \\
{[14]}\end{array}$ & UK & $\begin{array}{l}\text { GIS overlay } \\
\text { (MA) }\end{array}$ & $\begin{array}{l}\text { Climate data: annual } \\
\text { mean rainfall and } \\
\text { monthly mean } \\
\text { temperature from } 1971 \\
\text { to } 2000 \text { provided by } \\
\text { the UK Meteorological } \\
\text { Office }(1 \mathrm{~km}) \\
\text { - Weekly weather data: } \\
\text { derived from monthly } \\
\text { temperature data using } \\
\text { a continuous piecewise } \\
\text { quadratic functio }\end{array}$ & - & Own alteration & $\begin{array}{l}\text { Own } \\
\text { scenarios }\end{array}$ & - \\
\hline \multirow[t]{3}{*}{$\begin{array}{l}\text { ECDC } 2009 \\
{[16]}\end{array}$} & Europe & $\begin{array}{l}\text { Random forest } \\
\text { (CA) }\end{array}$ & $\begin{array}{l}\text { - World climatic zones } \\
\text { Temperature } \\
\text { data archive at } \\
\text { the University of } \\
\text { Daytona, US: daily } \\
\text { mean temperatures } \\
(1995-2007) \\
\text { - MODIS: day- and night- } \\
\text { time LST }(1 \mathrm{~km}) \\
\text { CRU: monthly mean } \\
\text { temperatures and } \\
\text { rainfall variables } \\
\text { averaged from } 1961 \text { to } \\
\text { 1990 (5 km) } \\
\text { NDVI and EVI }(1 \mathrm{~km})\end{array}$ & $\begin{array}{l}\text { - } n=1,525 \text { (presences } \\
\text { and absences, due } \\
\text { to centroids of } \\
\text { municipalities) } \\
\text { - training sample } \\
(n=300) \text {, divided over } \\
\text { both the presence } \\
(n=165) \text { and absence } \\
(n=135) \\
\text { - AUC }\end{array}$ & No projection & - & - \\
\hline & Europe & $\begin{array}{l}\text { GIS } \\
\text { overlay (CA) } \\
\text { sensu Medlock } \\
\text { et al. [14] }\end{array}$ & $\begin{array}{l}\text { - Same climate data } \\
\text { source as for the } \\
\text { random forest (CA) }\end{array}$ & - & No projection & - & - \\
\hline & Europe & MCDA (CA) & $\begin{array}{l}\text { - Same climate data } \\
\text { source as for the } \\
\text { random forest (CA) }\end{array}$ & - & $\begin{array}{l}\text { According to IPCC (no } \\
\text { further details) }\end{array}$ & $\begin{array}{l}\text { Minimal } \\
\text { and } \\
\text { maximum } \\
\text { impact } \\
\text { scenarios }\end{array}$ & $\begin{array}{l}2010 \\
2030\end{array}$ \\
\hline $\begin{array}{l}\text { Fischer et } \\
\text { al. } 2011 \\
\text { [17] }\end{array}$ & Europe & MaxEnt (CA) & $\begin{array}{l}\text { Worldclim: } 19 \\
\text { bioclimatic variables } \\
\text { derived from monthly } \\
\text { temperature, rainfall } \\
\text { values and altitude (10 } \\
\mathrm{km})\end{array}$ & $\begin{array}{l}\text { - Presence point data } \\
\text { worldwide }(\mathrm{n}=1,199) \\
\text { - Randomly selected } \\
\text { test }(30 \%) \text { and training } \\
\text { (70\%) data; the split } \\
\text { into training and test } \\
\text { data was replicated } 100 \\
\text { times } \\
\text { - AUC }\end{array}$ & $\begin{array}{l}\text { Regional climate model } \\
\text { COSMO-CLM rescaled } \\
\text { to } 10 \mathrm{~km}\end{array}$ & $\begin{array}{l}\mathrm{A}_{1} \mathrm{~B}^{\mathrm{a}} \\
\mathrm{B}^{\mathrm{a}}\end{array}$ & $\begin{array}{l}2011-2040, \\
2041-2070, \\
2071-2100\end{array}$ \\
\hline $\begin{array}{l}\text { Roiz et al. } \\
2011[18]\end{array}$ & $\begin{array}{l}\text { Trentino } \\
\text { (north- } \\
\text { east } \\
\text { Italy) }\end{array}$ & GLM (CA) & $\begin{array}{l}\text { Daily LST (MODIS Terra } \\
\text { and Aqua satellites), } \\
\text { reprojected to } 200 \mathrm{~m} \\
\text { - Human population data } \\
\text { from official population } \\
\text { census (2001) and } \\
\text { from Landscan Global } \\
\text { Population Database }\end{array}$ & $\begin{array}{l}\text { - Absence and presence } \\
\text { point data at } 145 \\
\text { sample stations } \\
\text { - AIC }\end{array}$ & $\begin{array}{l}\text { No specific climate } \\
\text { model: increase in mean } \\
\text { January temperature }(1.5 \\
\left.{ }^{\circ} \mathrm{C}\right) \text { and mean annual } \\
\text { temperature }\left(1^{\circ} \mathrm{C}\right) \text { with } \\
\text { respect to reference } \\
\text { period } 1961-1990\end{array}$ & $\mathrm{~A} 2^{\mathrm{a}}$ & $2040-2050$ \\
\hline $\begin{array}{l}\text { Caminade } \\
\text { et al. } 2012 \\
{[19]}\end{array}$ & Europe & $\begin{array}{l}\text { GIS overlay } \\
\text { (MA) } \\
\text { sensu } \\
\text { Kobayashi et } \\
\text { al. [20] and } \\
\text { Medlock et } \\
\text { al. [14], MCDA } \\
\text { sensu ECDC [16 }\end{array}$ & $\begin{array}{l}\text { - Gridded climate dataset } \\
\text { based on station } \\
\text { measurements at daily } \\
\text { and monthly temporal } \\
\text { resolution }\left(25 \mathrm{~km}^{2}\right)\end{array}$ & $\begin{array}{l}\text { - Absence and presence } \\
\text { data at the regional } \\
\text { administrative level of } \\
\text { the European Union } \\
\text { - AUC }\end{array}$ & $\begin{array}{l}\text { 10 selected regional } \\
\text { climate models } \\
\text { (ensembles), } 0.25{ }^{\circ} \text { step: } \\
\text { C4IRCA3, CNRM-RM4.5, } \\
\text { DMI-HIRAM5, ETHZ- } \\
\text { CLM, ICTP-RegCM } 3, \\
\text { KNMI-RACMO2), } \\
\text { METO-HC-HadRM } \\
\text { MPI-M-REMO, } \\
\text { OURANOSMRCC4.2.1, } \\
\text { SMHIRCA }\end{array}$ & $\mathrm{A}_{1} \mathrm{~B}^{\mathrm{a}}$ & $2030-2050$ \\
\hline $\begin{array}{l}\text { ECDC } 2012 \\
{[15]}\end{array}$ & Europe & $\begin{array}{l}\text { Non-linear } \\
\text { discriminant } \\
\text { analysis (CA) }\end{array}$ & $\begin{array}{l}\text { - Fourier transformation } \\
\text { of MODIS temperature } \\
\text { (Terra satellite) and } \\
\text { elevation data } \\
\text { - Worldclim data } \\
\text { - Human population } \\
\text { density from Global } \\
\text { Rural-Urban Mapping } \\
\text { Project }\end{array}$ & $\begin{array}{l}\text { - Thousands of } \\
\text { occurrence records via } \\
\text { existing databases and } \\
\text { own literature search } \\
\text { (for } A \text {. albopictus and } A \text {. } \\
\text { aegypti) } \\
\text { - Generation of } \\
\text { pseudo-absences via } \\
\text { environmental (MD) and } \\
\text { geographical distance } \\
\text { measure }\end{array}$ & No projection & - & - \\
\hline
\end{tabular}

AIC: Akaike`s Information Criterion; AUC: area under the receiver operator characteristic curve; CA: correlative approach; CRU: Climate Research Unit; ECDC: European Centre for Disease Prevention and Control; EVI: enhanced vegetation index; GIS: geographic information system; IPCC: Intergovernmental Panel on Climate Change; LST: land surface temperature; MA: mechanistic approach; MCDA: multi criteria decision analyses; MD: Mahalanobis distance; MODIS: Moderate Resolution Imaging Spectroradiometer; NDVI: normalised difference vegetation index UK: United Kingdom; US: United States.

a Emissions scenarios are based on the IPCC special report on emissions scenarios (SRES), where different storylines describe the relationships between the driving forces of climate change. The $\mathrm{A} 1 \mathrm{~B}$ scenario describes a future world of very rapid economic growth, global population that peaks in mid-century and declines thereafter and the rapid introduction of new and more efficient technologies. The A2 scenario assumes a continuously increasing global population, the economic development is primarily regionally oriented and per capita, economic growth and technological changes are more fragmented and slower than in other storylines. The B1 scenario is based on the assumption that economic structures will change rapidly towards a service and information economy and resource-efficient technologies will be introduced [26]. 
were used as presence or absence localities [27]. It should be noted that these municipalities differ in their spatial extent. The average area calculated from the political boundaries of the municipalities in southern Europe (e.g. Italy or Spain) may be up to three times bigger than in those in central Europe (e.g. Germany), which limits the ability to account for landscape heterogeneity. The centroids indicating species presences or absences are correlated with 57 (standardised) climate data layers, from which four variables are chosen as predictors via a backward stepwise procedure. All selected predictors are related to temperature.

Another approach recently published in a later ECDC technical report, The climatic suitability for dengue transmission in continental Europe, is based on multivariate discriminant analyses [15]. Again, this approach concentrates on modelling the current climatic suitability for A. albopictus. Here, global occurrence of this species was used as a model input. Accounting for the global dimension offers the opportunity to include the entire environmental space occupied by the species. However, this neglects the role of adaptation in regional populations. As discriminant analyses require absence records, (global) pseudo-absences were generated by evaluating localities that were geographically and environmentally dissimilar to presences. The models aim to discriminate between these two categories using the predictor variables available. The final risk maps were produced by averaging over 100 bootstrap samples [15].

\section{Presence-only models}

Many insect databases rely on documented presence localities, especially if a species is globally distributed. As the generation of pseudo-absences is ambitious (see [15]), novel ways to cope with presence-only data have been developed. In presence-only models, relationships are based on comparison of a species presence with the environmental background. Within this environmental background, the species were not recorded, which could also mean that data collection was not attempted in the respective region. Thus, at those sites, no information on the suitability of the environment or climate exists.

Employing the correlative environmental niche model Genetic Algorithm for Rule-set Prediction (GARP), Benedict et al. determined the global risk of invasion by $A$. albopictus [24]. A model built with GARP is iteratively chosen from non-random correlations between environmental and occurrence data. The nonrandom correlations describe environmental thresholds, depending on the chosen type of mathematical rule. Apparently, A. albopictus occupies different environmental niches on the invaded continents, which is revealed by Medley by applying correlative niche models for isolated geographical occurrence localities from the native and invaded range [25]. For all comparisons, the niche for introduced distributions was not equivalent to the native niche. For this purpose, Medley [25] applied the Maximum Entropy approach (implemented in MaxEnt software) [28]. MaxEnt has replaced GARP as a preferred modelling algorithm for presence-only data during the past years, due to improved model performance [23]. The idea behind MaxEnt is to find the probability distribution of maximum entropy (most spread out) that is subject to constraints imposed by information available on the species presence and the environmental conditions across the study area $[28,29]$.

\section{Distribution models that consider climate change projections}

Until November 2012, there were four studies that aimed to determine potential future climatic suitability of $A$. albopictus in Europe (summarised in Table 1 and 2) [16-19]. In two studies [16,19], climatic suitability was projected via mechanistic models, while the results of the two other studies $[17,18]$ were based on correlative approaches. One study [18] was applied to a limited study region, while the other three $[16,17,19]$ cover the entire European continent. In order to detect methodological qualities and constraints, these studies are compared in detail.

Information concerning input data is given including: climate variables, model validation and source and steps, e.g. of climate data for the respective emission scenario as well as addressed future time steps.

Mechanistic approaches

Within the technical report of the ECDC, a mechanistic multi criteria decision analysis (MCDA) was performed [16]. In contrast to the correlative approaches of this report, the results of the MCDA were projected to future conditions. An MCDA is a structured tool within a decision support framework. This enables evaluation of multiple decision constraints based on previously defined estimation criteria. The exploration of such decision alternatives for complex problem settings was recently developed within GIS frameworks in order to achieve accurate spatial risk assessment of vectors and vector-borne diseases [30]. In order to detect climatic suitability for $A$. albopictus, sigmoidal or symmetric sigmoidal membership functions were generated for the standardised variables and combined linearly with equal weight [16]. This was done based on expert advice. Generally, MCDA applications for spatial pattern analysis offer an opportunity to identify gaps and limits in knowledge; however, they are limited in determining causality [30]. Projections were applied for the MCDA approach and applied to the expected situation in 2010 and 2030, using SRES-scenarios with minimal or maximal impact [25]. Detailed information concerning the climate model and scenario characteristics was not given.

The mechanistic approaches used by Kobayashi et al. [20], Medlock [14] and the MCDA by ECDC [16] were adapted by Caminade et al. [19]. In contrast to previous approaches, Caminade et al. evaluated model performance via the area under the receiver operator 
TABLE 2A

Variables and model set-up in studies addressing current and projected climatic suitability of Aedes albopictus in Europe

\begin{tabular}{|c|c|c|}
\hline Study & Variables & Method \\
\hline $\begin{array}{l}\text { Medlock et al. } 2006 \\
{[14]}\end{array}$ & $\begin{array}{l}\text { Overwintering criteria } \\
\text { - Mean January temperature }>0{ }^{\circ} \mathrm{C} \\
\text { - Annual mean rainfall }>500 \mathrm{~mm} \\
\text { Spatio-temporal activity } \\
\text { Scenario } 1 \\
\text { Low risk } \\
\text { - Spring mean temperature } 10-10.5^{\circ} \mathrm{C} \\
\text { - Spring photoperiod } 11-11.25 \mathrm{~h}(\mathrm{daylight}) \\
\text { - } \text { Temperature for cessation of egg/larval activity }<9.5^{\circ} \mathrm{C} \\
\text { - Critical photoperiod for autumn diapause } 13-13.25 \mathrm{~h} \\
\text { Medium risk } \\
\text { - Spring mean temperature } 10.5-11{ }^{\circ} \mathrm{C} \\
\text { - Spring photoperiod } 11.25-11.5 \mathrm{~h} \\
\text { - Temperature for cessation of egg/larval activity } 9.5-10{ }^{\circ} \mathrm{C} \\
\text { - Critical photoperiod for autumn diapause } 13.5-14 \mathrm{~h} \\
\text { High risk } \\
\text { - Spring mean temperature }>11{ }^{\circ} \mathrm{C} \\
\text { - Spring photoperiod }>11.5 \mathrm{~h} \\
\text { - Temperature for cessation of egg/larval activity }>10{ }^{\circ} \mathrm{C} \\
\text { - Critical photoperiod for autumn diapause }>14 \mathrm{~h} \\
\text { Scenario } 2 \\
\text { - Critical photoperiod for autumn diapause } 11 \mathrm{~h}, 11.5 \mathrm{~h} \text { and } 12 \mathrm{~h} \text { for } \\
\text { high, medium and low risk, respectively. The other three parameters } \\
\text { stay the same. Photoperiod is based on astronomical equations of } \\
\text { sunrise and sunset. }\end{array}$ & $\begin{array}{l}\text { GIS-based overlay } \\
\text { Assessing the potential for survival } \\
\text { and spatio-temporal activity dynamics } \\
\text { (number of weeks between the first } \\
\text { hatching of overwintered eggs in spring } \\
\text { and the production of diapausing eggs) }\end{array}$ \\
\hline $\begin{array}{l}\text { ECDC } 2009[16] \\
\text { GIS overlay }\end{array}$ & $\begin{array}{l}\text { Adapted by Medlock et al. [14] but no overwintering criteria } \\
\text { - Critical photoperiod for autumn diapause } 13.5 \mathrm{~h} \\
\text { - Spring photoperiod } 11-11.5 \mathrm{~h} \\
\text { - Spring mean temperature } 10-11{ }^{\circ} \mathrm{C}\end{array}$ & $\begin{array}{l}\text { GIS-based overlay sensu Medlock et al. } \\
\text { [14] }\end{array}$ \\
\hline $\begin{array}{l}\text { ECDC } 2009[16] \\
\text { Random forest }\end{array}$ & $\begin{array}{l}\text { Four predictor variables chosen from } 57 \text { data layers } \\
\text { - Maximum night-time LST } \\
\text { - Mean annual daytime LST } \\
\text { - Minimum daytime LST } \\
\text { - Second amplitude of daytime LST }\end{array}$ & $\begin{array}{l}\text { Random forest } \\
\text { - } 200 \text { aggregated classification trees } \\
\text { for classification } \\
\text { - Stepwise backward reduction of the } \\
\text { number of variables until accuracy } \\
\text { dropped below } 90 \% \text {. }\end{array}$ \\
\hline $\begin{array}{l}\text { ECDC } 2009[16] \\
\text { MCDA }\end{array}$ & $\begin{array}{l}\text { Annual mean rainfall } \\
\text { - No suitability }\langle 450 \mathrm{~mm} \\
\text { - Maximum suitability }>800 \mathrm{~mm} \\
\text { Summer temperature (June-August) } \\
\text { - No suitability }\left\langle 15^{\circ} \mathrm{C} \text { or }>30^{\circ} \mathrm{C}\right. \\
\text { - Maximum suitability } 20-25^{\circ} \mathrm{C} \\
\text { Mean January temperature } \\
\text { - No suitability }<-1{ }^{\circ} \mathrm{C} \\
\text { - Maximum suitability }>3{ }^{\circ} \mathrm{C}\end{array}$ & $\begin{array}{l}\text { MCDA } \\
\text { - Sigmoidal transformation of mean } \\
\text { annual rainfall and temperature in } \\
\text { January } \\
\text { - Symmetrical sigmoidal transformation } \\
\text { of summer temperatures } \\
\text { - Linear combination for suitability } \\
\text { data layers, whereby each factor was } \\
\text { assigned with equal weight }\end{array}$ \\
\hline $\begin{array}{l}\text { Fischer et al. } 2011 \\
\text { [17] } \\
\text { Expert knowledge- } \\
\text { based model }\end{array}$ & $\begin{array}{l}\text { Selection from } 20 \text { bioclimatic variables } \\
\text { - Annual mean temperature } \\
\text { - Mean temperature of the warmest quarter } \\
\text { - Mean temperature of the coldest quarter } \\
\text { - Annual precipitation } \\
\text { - Altitude }\end{array}$ & $\begin{array}{l}\text { MaxEnt } \\
\text { - Selection of variables based on expert } \\
\text { knowledge }\end{array}$ \\
\hline $\begin{array}{l}\text { Fischer et al. } 2011 \\
{[17]} \\
\text { Statistic based model }\end{array}$ & $\begin{array}{l}\text { Selection from } 20 \text { bioclimatic variables } \\
\text { - Annual mean temperature } \\
\text { - Annual precipitation } \\
\text { - Precipitation of the warmest quarter } \\
\text { - Precipitation of the coldest quarter } \\
\text { - Altitude }\end{array}$ & $\begin{array}{l}\text { MaxEnt } \\
\text { - Jackknife test to measure variables } \\
\text { importance } \\
\text { - Calculations of models' training gains } \\
\text { for variables in isolation and for } \\
\text { remaining dataset if this variable is } \\
\text { dropped }\end{array}$ \\
\hline Roiz et al. 2011 [18] & 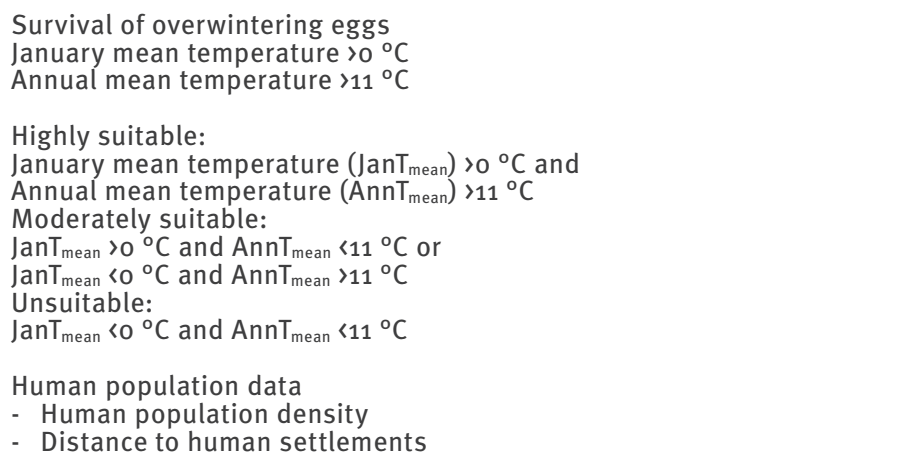 & $\begin{array}{l}\text { GLM with binomial distribution (multiple } \\
\text { logistic regression) } \\
\text { - Relating species' presences/ } \\
\text { absences to variables }\end{array}$ \\
\hline
\end{tabular}


Variables and model set-up in studies addressing current and projected climatic suitability of Aedes albopictus in Europe

\begin{tabular}{|c|c|c|}
\hline Study & Variables & Method \\
\hline $\begin{array}{l}\text { Caminade et al. } 2012 \\
{[19]} \\
\text { Model } 1\end{array}$ & $\begin{array}{l}\text { Annual mean temperature } \\
\text { - Totally suitable }>12^{\circ} \mathrm{C} \\
\text { - High risk } 11-12{ }^{\circ} \mathrm{C} \\
\text { - Moderate risk } 10-11{ }^{\circ} \mathrm{C} \\
\text { - Low risk } 9-10{ }^{\circ} \mathrm{C} \\
\text { Overwintering criterion } \\
\text { Highly unsuitable } \\
\text { - Mean January temperature }<0^{\circ} \mathrm{C} \\
\text { - Annual mean rainfall }<500 \mathrm{~mm} \\
\text { Medium unsuitable } \\
\text { - Mean January temperature } 0-1{ }^{\circ} \mathrm{C} \\
\text { - Annual mean rainfall } 500-600 \mathrm{~mm} \\
\text { Low unsuitable } \\
\text { - Mean January temperature } 1-2{ }^{\circ} \mathrm{C} \\
\text { - Annual mean rainfall } 600-700 \mathrm{~mm} \\
\text { Suitable } \\
\text { - Mean January temperature }>2{ }^{\circ} \mathrm{C} \\
\text { - Annual mean rainfall }>700 \mathrm{~mm}\end{array}$ & GIS-based overlay sensu Kobayashi et al. [20] \\
\hline $\begin{array}{l}\text { Caminade et al. } 2012 \\
\text { [19] } \\
\text { Model } 2\end{array}$ & See ECDC [16] (MCDA) & MCDA sensu ECDC [16] \\
\hline $\begin{array}{l}\text { Caminade et al. } 2012 \\
{[19]} \\
\text { Model } 3\end{array}$ & $\begin{array}{l}\text { Overwintering criterion (see model } 1 \text { ) } \\
\text { Weeks of activity } \\
\text { - Mean weekly temperatures } \\
\text { - Mean weekly photoperiods } \\
\text { Hatching onset (medium scenario) } \\
\text { - Spring temperature }>10.5{ }^{\circ} \mathrm{C} \\
\text { - Photoperiod }>11.25 \mathrm{~h} \\
\text { Autumn diapause } \\
\text { - Temperature }>9.5{ }^{\circ} \mathrm{C} \\
\text { - Photoperiod }>13.5 \mathrm{~h}\end{array}$ & $\begin{array}{l}\text { GIS-based seasonal activity model sensu Medlock et } \\
\text { al. [14] } \\
\text { Overwintering criterion to mask the areas where the } \\
\text { mosquito would not be able to survive } \\
\text { - Photoperiod calculation as the period between } \\
\text { sunrise and sunset } \\
\text { - Computation of the start of spring hatching and } \\
\text { autumn egg diapause is based on medium scenario }\end{array}$ \\
\hline ECDC $2012[15]$ & $\begin{array}{l}\text { Clear documentation of pre-processing MODIS data; no } \\
\text { further information about the chosen variables }\end{array}$ & $\begin{array}{l}\text { Non-linear discriminant analysis } \\
\text { - Preliminary k-means cluster analysis to analyse } \\
\text { outliers in training set for exclusion in modelling } \\
\text { process } \\
\text { - } 100 \text { random bootstrap samples with equal number } \\
\text { of presences and absences } \\
\text { - Stepwise inclusion of } 10 \text { environmental variables } \\
\text { - } 100 \text { results were averaged to produce the final risk } \\
\text { maps }\end{array}$ \\
\hline
\end{tabular}

GIS: geographic information system; GLM: generalised linear model; LST: land surface temperature; MCDA: multi criteria decision analyses; MODIS: Moderate Resolution Imaging Spectroradiometer.

characteristic curve (AUC) [19]. AUC is based on signal detection theory and illustrates the performance of a binary classifier system when the discrimination threshold varies. Hence, it is typically used to determine performance of correlative niche models. Although it is a mechanistic approach, presence and absence localities based on centroids created from administrative level are generated [27]. These data were used as an evaluation of their results of the mechanistic classification in order to measure model performance. A novel feature was that Caminade et al. considered the role of climate change in Europe in past years (1960-1989, 1990-2009, 2005-2009) in the spread of the mosquito [19]. Furthermore, ensemble data of climate change projections were used, which were given by 10 regional climate models. Regional climate models are driven, at their boundaries, by global climate models. Employing ensemble data enables variations of future projections to be assessed and, consequently, reduces uncertainty [31]. Usually, projections based on ensemble data include a multitude of potential variations by averaging over all possible developments. In the study of Caminade et al., projections were solely based on the A1B emission scenario [19]. The A1 storyline describes a future world with very rapid economic growth and a rapid introduction of new and more efficient technologies. Thereby, the global population peaks mid-century and declines thereafter. In the A1B scenario, a balanced use across all energy resources is expected [26].

\section{Correlative approaches}

Previous findings hint towards niche shifts of $A$. albopictus during the global invasion process [25]. In order to account for this, Fischer et al. applied two models 
built on presence-only data beyond the European distribution with MaxEnt [17]. Firstly, global occurrence was used for training. Secondly, the native (Asian) distribution served as a training region. Both models were tested for the current European climatic conditions. The database contains more than 6,000 occurrence records of which 1,200 were selected as model input. The initial database was reduced by using geographically weighted correction to minimise spatial bias and autocorrelation in data. Geographically explicit point localities were taken from the literature and completed with presences reported on county level from the United States for the generation of the global database. The problematic issue with political or administrative borders in datasets was mentioned before. While the native range models, containing the Asian distribution and environments, fail to predict the current distribution in Europe, the global-trained model predicts the current European distribution with highly satisfactory quality. This suggests the use of the entire "climatic niche' for projections. Two sets of bioclimatic variables provided by WorldClim (global climate data) [32] were used as model input. The first set was based on expert knowledge on species' ecology. The second set was chosen via statistical tests to determine the highest explanatory power of the model. All models were validated with AUC values. As both the expert knowledgeand statistical-based models of the global range yield high AUC values, they were both projected to future climate conditions in Europe. The training region seemed to be more important than the chosen set of climatic variables. Projections were based on data given by the regional climate model COSMO-CLM, applying the two scenarios $A_{1} B$ and $B_{1}$. The $A_{1} B$ scenario has been described above. The $B_{1}$ storyline describes the same development of the global populations in a globalised world, as in the $A_{1} B$ scenario, but with a rapid change in economic structures towards a service- and information-oriented economy with environmental sustainability [26]. The B1 scenario is a rather moderate scenario and corresponds to the aim of the European Union of keeping anthropogenic warming below 2 Kelvin in comparison to the pre-industrial level [33]. Non-analogue climate is a problematic issue in species distribution modelling, as the observed distribution of a species provides no information about species response under novel climates, e.g. $[22,34,35]$. Hence, projections (in space and/or time) to regions with non-analogue climate are biased and require caution in interpretation. In the study of Fischer et al. [17], however, non-analogue climate in projections were excluded via multivariate environmental similarity surface analysis as state-of-the-art evaluation (see [36]).

Roiz et al. focused on the potential spread of $A$. albopictus to higher altitudes in the Alps of northern Italy using binomial generalied linear model (GLM) as a logistic regression [18]. They related presences and absences of $A$. albopictus in ovitraps to land surface temperature (LST) data from satellite and human population data. Multiple years of daily LST data from the Moderate Resolution Imaging Spectroradiometer (MODIS) were reprocessed at increased spatial resolution of $200 \mathrm{~m}$ pixels. The geographically explicit presence/absence data offers the opportunity to correlate them with the background data at this high spatial resolution. A temperature-gradient-based model was used to fill no-data areas from more than 11,000 daily MODIS LST scenes from 2000 to 2009. On the basis of this, threshold conditions for the survival of eggs in the winter, alongside the survival of the adults, were determined. The best models were selected via Akaike's Information Criterion (AIC). AIC is grounded on the concept of information entropy and evaluates the information loss, when a given model should describe reality. It can be interpreted as a trade-off between model accuracy and complexity. In concurrence with previous results [20], Roiz et al. identified annual mean temperature $\left(11{ }^{\circ} \mathrm{C}\right)$ and January mean temperature (o ${ }^{\circ} \mathrm{C}$ ) as best predictors for identifying areas suitable for $A$. albopictus establishment [18]. Applying the A2 scenario, they considered an increase of the annual mean temperature of 1 and 1.5 Kelvin in winter in order to simulate the expected climatic conditions in 2050. Using data obtained directly from regional climate models would be inappropriate as these data are given in a resolution of $10-20 \mathrm{~km}$. The A2 storyline describes a heterogeneous regionally oriented world and economy with a continuously increasing global population. Warming tendencies are more pronounced than in the previously described $\mathrm{A} 1 \mathrm{~B}$ and $\mathrm{B} 1$ scenarios [26].

\section{Evaluation of climate change effects \\ on the habitat suitability}

Evidently, several distribution modelling efforts have been used to project the future climatic suitability of A. albopictus in Europe, which differ in model algorithm, climate data and scenarios. Here, we generated a simple GIS overlay (Figure $1 \mathrm{~A}$ ) to compare the risk map from the technical report of ECDC [16] with the results from Fischer et al. [17] and Caminade et al. [19]. However, an accurate comparison concerning the results of future projections cannot be presented, for several reasons. Firstly, there were clear differences regarding the chosen time-steps, emission scenarios and spatial resolution (Tables 1 and 2). Secondly, both, geographical and projected coordinate systems were used in the different studies. Hence, the comparison must be considered as a schematic and qualitative generalisation rather than a quantitative detailed compilation. Furthermore, we labelled localities with documented establishments of $A$. albopictus with the colour of the local climatic suitability (Figure $1 \mathrm{~B}$ ), to indicate how accurate the models reflect these occurrences. In general, the models under investigation were capable of predicting well the current localities of $A$. albopictus in Europe (Figure 1B). Only a few presences were observed in regions with rather unsuitable conditions. 
Projections of climatic suitability of Aedes albopictus in Europe (A) and in European localities with documented establishment of $A$. albopictus (B)

A. Projection of climatic suitability in Europe

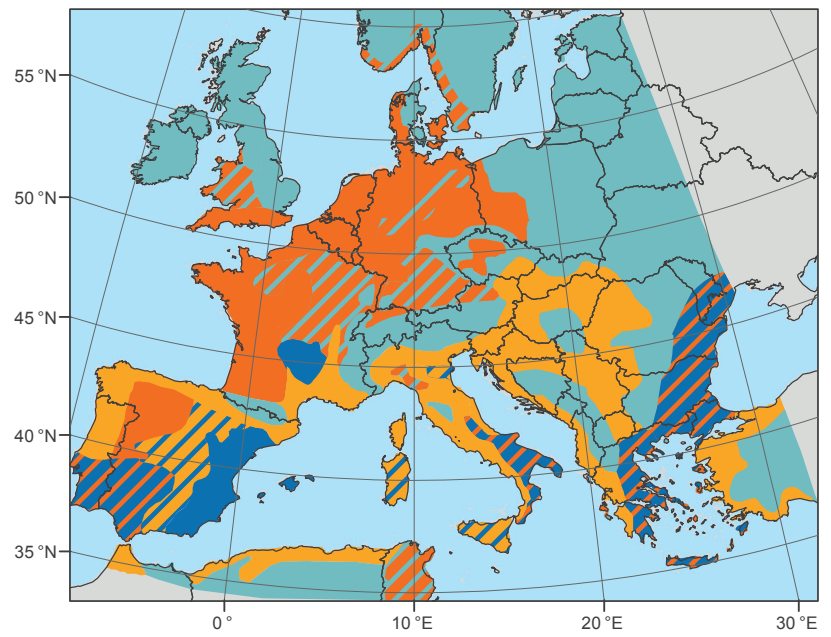

B. Localities with documented establishment of $A$. albopictus

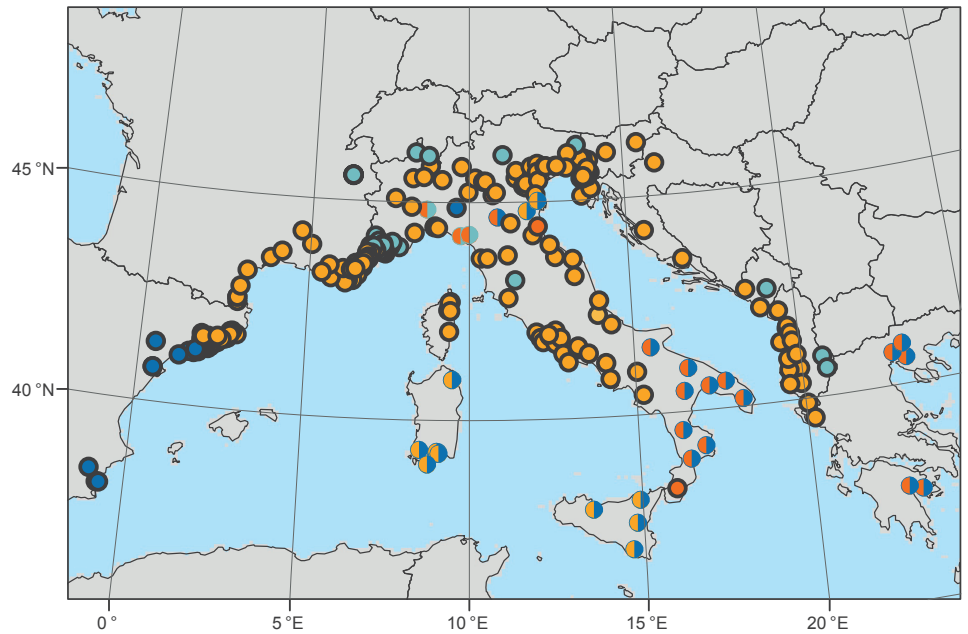

Expected tendencies in climatic conditions for $A$. albopictus up to the mid-21st century

Persistently suitable

Increasingly suitable

Persistently unsuitable

Increasingly unsuitable

\begin{abstract}
Dersistently unsuitable to increasingly suitable
20. Persistently suitable to increasingly unsuitable

Increasingly suitable to increasingly unsuitable

Documented establishment of $A$. albopictus
\end{abstract}

A. Evaluation of projections of climatic suitability of $A$. albopictus within the first half of the 21st century in Europe in comparison with the situation at the end of the 2oth century. Results of the mechanistic models based on multi criteria decision analyses of ECDC [16] and Caminade et al. [19] were compared with the statistical-based correlative niche model of Fischer et al. [17]. This is simply a schematic and qualitative generalisation, due to differences in time periods, scenarios and spatial resolution.

B. The records are coloured according to the evaluation of the changing climatic suitability of $A$. albopictus (ranging from the end of the 20 th century up to the first half of the 21st century) presented in panel A.

\section{General trends arising from comparison of the studies}

Regardless of the above-mentioned differences and obstacles for comparisons, some general tendencies concerning the evolving climatic suitability for A. albopictus in Europe within the first half of the 21st century can be derived. Projections indicate that climatic suitability will especially increase in many regions where the species is not yet established. Regions that are currently characterised by a rather low or moderate suitability have the potential for invasion by midcentury, due to increasing climatic suitability (Figure $1 \mathrm{~A})$. As a general tendency of all studies at the continental scale $[16,17,19]$ it can be inferred that especially western Europe (Belgium, France, Luxembourg and the Netherlands) will provide favourable climatic conditions within the next decades. Furthermore, climatic suitability can be expected to increase in central Europe (e.g. parts of Germany) and the southernmost parts of the United Kingdom. Climatic conditions will continue to be suitable in southern France, as well as most parts of Italy and Mediterranean coastal regions in south-eastern Europe. Astonishingly, decreasing suitability for $A$. albopictus is projected for the western Mediterranean coast of Spain. This is very likely a consequence of an increased expectancy of drier conditions during the summer months.

However, some uncertainties in projections of the different studies are worth mentioning (see Figure 1A): differences between projections are evident in France, Germany, and western parts of the United Kingdom (Wales), where projections range from persistently unsuitable to increasingly suitable. In central parts of the Iberian Peninsula, Sardinia and Sicily, it is uncertain whether climatic conditions will continue to be suitable or will become less suitable in the future. Deviations between projections are most pronounced in the south-western parts of the Iberian Peninsula, south-eastern Italy and parts of eastern parts of Greece including also the west coast of the Black Sea. In these regions, uncertainties in model outputs vary strongly in projections: climatic suitability is expected to persist or increase in the projections of ECDC [16] and Caminade et al. [19], while Fischer et al. [17] identified decreasing climatic suitability. Generally, projections are more sensitive to uncertainties for precipitation 
End of the 20th century (A) and projected (2011-2040) (B) climatic suitability of Aedes albopictus in Europe, with locations of important harbours

A. End of the 2oth century

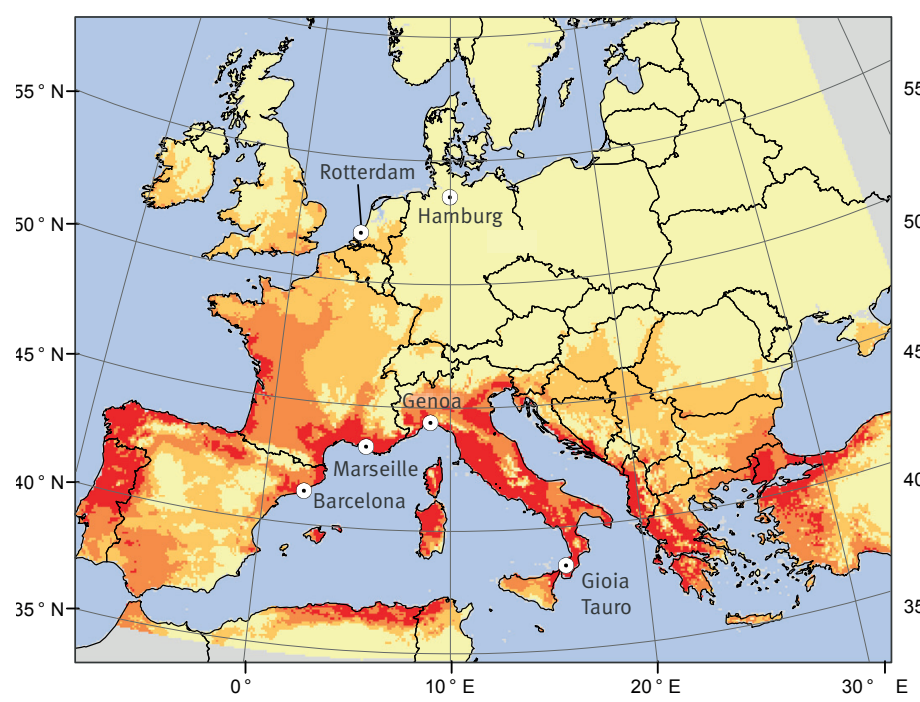

B. $2011-2040$

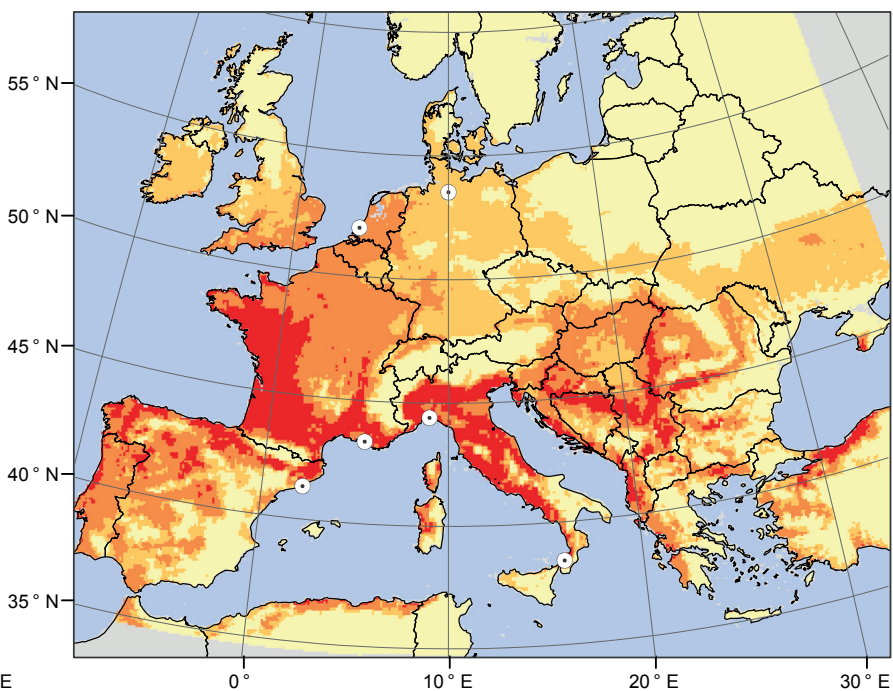

Climatic suitability for $A$. albopictus

$0.00-0.20$

$\square \quad 0.21-0.40$

$\square .41-0.60$

$0.61-0.80$

- Harbours

Data concerning the current and projected climatic suitability (A1B scenario) for $A$. albopictus refer to results of the statistical-based niche model of Fischer et al. [17]. Values for establishment theoretically range from o (completely unfavourable) to 1 (extremely favourable).

Additionally, the changes in climatic suitability for 2011 to 2040 become obvious. Suitability will increase for the biggest European harbours of Rotterdam and Hamburg, which marks these as potential gateways for unintended mosquito introduction. In order to account for areas involved in cargo transport on a regional scale, we created buffer zones with different radii around the harbours of Rotterdam, the Netherlands, and Hamburg, Germany. This was done in order to detect examples of climatic suitability of the regions surrounding harbours with expected container transport. Climatic suitability was averaged for each buffer zone. Currently, climatic suitability is rather low for regions around Hamburg (radius (r) $50 \mathrm{~km}=0.12 \pm 0.01 ; \mathrm{r} 100 \mathrm{~km}=0.12 \pm 0.02 ; \mathrm{r} 200 \mathrm{~km}=0.11 \pm 0.03$ ), while moderate suitability can be found for areas around Rotterdam ( $50 \mathrm{~km}=0.21 \pm 0.02 ; \mathrm{r} 100 \mathrm{~km}=0.23 \pm 0.05 ; \mathrm{r} 200 \mathrm{~km}=0.23 \pm 0.07$ ). For 2011 to 2040 , suitability of both regions of interest will increase remarkably. Regions around Hamburg will provide moderate suitability $(\mathrm{r} 50 \mathrm{~km}=0.27 \pm 0.03 ; \mathrm{r} 100 \mathrm{~km}=0.28$ $\pm 0.05 ; \mathrm{r} 200 \mathrm{~km}=0.29 \pm 0.06$ ), while climatic suitability will even favour establishment of $A$. Albopictus in zones around Rotterdam ( $50 \mathrm{~km}=$ $0.50 \pm 0.03 ; r 100 \mathrm{~km}=0.51 \pm 0.03 ; \mathrm{r} 200 \mathrm{~km}=0.48 \pm 0.05)$.

than for temperature, which is particularly evident in southern Europe. Compared with the studies of ECDC [16] and Caminade et al. [19], the influence of precipitation in climatic suitability is more pronounced within the statistical-based model of Fischer et al. [17] (see also Table 2).

\section{Further trends to be expected}

The general trend of increasing climatic suitability in regions that are currently rather unfavourable for A. albopictus establishment leads to the assumption of a northward spread in western but also central Europe up to the middle of the century. This is the time frame of results published by ECDC [16] and Caminade et al. [19]. From then on, trends can only be obtained by accounting solely for the study of Fischer et al. [17]. According to their projections, climatic suitability will further increase in central Europe and climate will become suitable for mosquito establishment in eastern Europe during the second half of the century [17].
Besides the continental dimension, potential range expansions on a local scale become crucial for the spread of $A$. albopictus in Europe as well. For instance, increasing temperatures may facilitate an upward spread in alpine regions, which has been demonstrated in northern Italy (Trentino) [18].

\section{Future research avenues}

In a warmer world, invasion processes of species may exhibit novel dynamics [37,38]. Thus, new challenges arise concerning the surveillance of invasive mosquitoes in Europe with high ability to colonise new territories as it is the case with A. albopictus [39]. Future research addressing invasive species that are of societal importance (e.g. regarding health issues) requires a comprehensive strategy for embedding climatic risk analyses in a broader scientific context. The main issues, such as transport mechanisms, alterations of habitats due to climatic extremes and biotic interactions, are highlighted below, as they are the most challenging tasks in modelling. 


\section{Continental dispersal pathways}

None of the studies on potential future European occurrence of $A$. albopictus explicitly addresses processes such as the introduction and dispersal of the species. The introduction of this mosquito in Europe can be attributed to the global shipping of goods, especially by the world trade of used tyres or the import of tropical plants such as 'Lucky Bamboo' (Dracaena braunii) $[1,2]$. Undoubtedly, shipping is extremely effective in overcoming long-distance oceanic barriers [2,40,41]. Thus, the intercontinental range expansions of A. albopictus proved to be predictable using this combination of frequencies and traffic volumes of shipping lines in combination with climatic data at the target region around harbours [35]. The establishment of A. albopictus evidently took place around Mediterranean harbours, e.g. around the seaports of Genoa, La Spezia and Gioia Tauro in Italy as well as Barcelona, Spain regions that are considered to be climatically suitable for the species today (Figure 2).

Intensified monitoring systems are installed in harbour regions at higher latitudes. After introduction, A. albopictus populations were found in glasshouses in the Netherlands used by Lucky Bamboo importers [42]. Such unintended import of the mosquito to the Netherlands seems to be a repeated phenomenon [43], although no evidence consists concerning the establishment of $A$. albopictus in Dutch landscapes. This is probably related to their low climatic suitability. This is also still true for other regions around the most important European harbours of Rotterdam, the Netherlands, and Hamburg, Germany,) that are characterised by the highest number of import containers, coming from endemic regions. Obviously, the harbours are not the final destination of the containers, as they are transported to the continental interior. We calculated the averaged climatic suitability within buffer zones of different radii $(50-200 \mathrm{~km})$ around the harbours of Rotterdam based on the results of Fischer et al. [17]. Increasing climatic suitability within these buffer zones around the introduction gateways may become crucial for future $A$. albopictus spread (Figure 2).

Once $A$. albopictus has been introduced and established, the question arises how to determine the risk of the mosquitoes spreading to further potentially climatically suitable habitats. Using the example of sandflies, it has been demonstrated that the dispersal of disease vectors on the continental scale can be evaluated by creating artificial cost surfaces that include several landscape features that are attributed with cost factors [44]. Consequently, the pathway with least costs for a species' dispersal can be considered as the most likely path of the species to move across landscapes. However, in contrast to sandflies, the dispersal of $A$. albopictus is mainly driven by unintended human transport through trade and traffic as opposed to natural dispersal. Hence, accounting anthropogenic factors in dispersal analyses is ambitious and acquires attribution of (rail-) roads and resting places in analyses. Consideration of these dispersal mechanisms, combined with current risk mapping and climate change assessments, suggests that further expansion across much of Europe is probable [2]. The necessity of dispersal analyses on the continental scale is highlighted by the recent incursion of $A$. albopictus in south-westernmost parts of Germany [45]. Thus, it has been concluded that $A$. albopictus crossed the Alps via transportation on motorways [46]. Another striking example is the recent importation of the mosquito to southernmost parts of the Czech Republic due to transit traffic [47]. Further spreading pathways need to be identified, as invasive mosquitoes may also be adaptable to new environments in a target region $[2,36,48,49]$. Without human transportation, the spreading potential of $A$. albopictus is limited to the local scale. In Italy, a flight range up to $300 \mathrm{~m}$ around their breeding containers has been observed [50]. This short-distance natural dispersal can be only assessed with high-resolution (250 $\mathrm{m}$ pixel resolution), gap-filled daily LST satellite data to predict areas that are potentially affected by infestation of $A$. albopictus $[51,52]$.

\section{Climatic constraints and novel scenarios}

Integration of expert knowledge in modelling approaches demands detailed information on mosquitoes' ecology. In temperate regions, diapausing is a strategy to maintain species' typical life cycle traits, as diapausing eggs show remarkable desiccation resistance aside from increased cold tolerance [53]. In Italy, either favourable microclimates or cold acclimation may play a decisive role in the context of overwintering [54]. Likewise overwintering was identified as a constraint also in Switzerland [52]. Under laboratory conditions, the low-temperature thresholds for the survival of eggs of European populations of $A$. albopictus have been identified [55]. Such experiments help to detect potential regions, capable of overwintering populations. To date, information is mostly obtained by field observations; however, the thresholds for survival can be derived by simulating extremes that then can be transferred to climate change scenarios.

Currently, the development of the next generation of IPCC climate change scenarios is under way. Until now, a sequential approach has been used for scenario development [56]. These scenarios depict a linear chain of causes and consequences of anthropogenic climate change, handed from one research community to the next in a lengthy process, leading to inconsistencies. The new parallel process begins with the identification of radiative forcing characteristics that support modelling a wide range of possible future climates. In parallel, new socio-economic scenarios will be developed to explore important socio-economic uncertainties affecting both adaptation and mitigation. This is directly linked to, and integrated within, the new climate scenarios $[5,57]$. The extensive exchange between scientific disciplines acquired a more sophisticated design matching. Then, projections based on climatic extremes and their ecological consequences 
will be improved. To date, projections concerning future climatic suitability of $A$. albopictus in Europe are based on long-term changes and do not consider the decisive role of rather short-term extremes. Modified climatic variability and associated sporadic extreme conditions are likely to create windows of opportunity for the establishment and reproduction of disease vectors such as $A$. albopictus, even if this is not reflected in trends of long-term average values [58].

Projections for the climatic suitability of $A$. albopictus can be combined, for instance, with the temperaturedependent extrinsic incubation period of an arbovirus, the time between pathogen infection of the insect vector and the vector's ability to infect the next vertebrate host. An accurate risk assessment of a climate-driven shift or spread of a vector-borne disease can then be obtained by combining risk maps of vector and transferred pathogen amplification in the light of a rapidly changing European climate for dengue $[15,59,60]$ or chikungunya [61,62].

\section{Further challenges for risk assessment}

Aside from the above-mentioned novel opportunities, some challenges pertaining to future developments and their analyses need to be mentioned. A combination of phylogenetic analyses with distribution models was used to reconstruct the spatial occurrence of A. albopictus during the Pleistocene [63]. Such combined approaches seem to be a promising effort to support future projections. However, mutations and rapid adaptations of short-lived species to changing environment must be expected. Furthermore, outside of its native range $A$. albopictus acts as a strong competitor to local mosquitoes [49]. This not only affects the vectors' occurrence, but also the activity phase and population dynamics [64].

As $A$. albopictus prefers anthropogenic habitats, modified human behaviour is also a source of uncertainty. For instance, humans provide breeding sites for this container-breeder that enable survival in dry regions due to water storage [40]. Thus, changes in human behaviour or more general in human societies demand a comprehensive philosophy that must be implemented in risk assessments of climate change effects on emerging diseases. Estimating climatic suitability should be considered as a first step in risk assessment. Once future climatic suitability is detected for specific regions, societal and demographic aspects must be considered and regional specifics of healthcare systems can then be designed in a more specific and efficient way [65-67]. Such hierarchical and logical strategies may contribute to lowering the risks of vector spread and pathogen transmission. Recently, ECDC has launched the E3 Geoportal as a (spatial) data dissemination platform to facilitate data sharing and usability [68]. In order to guarantee accuracy for environmental risk mapping of $A$. albopictus, a proof of concept was given [69]. Furthermore, ECDC initiated research activities on assessing the related risk of chikungunya [62] and dengue virus transmission in Europe [70].

\section{Acknowledgments}

Stephanie M. Thomas and Nils B. Tjaden received financial support from the Bavarian State Ministry of the Environment and Public Health (Project: ZKLo1Abt7_60875). Markus Neteler was partially funded by the Autonomous Province of Trento (Italy), Research funds for Grandi Progetti, Project LexEM (Laboratory of excellence for epidemiology and modeling, http://www.lexem.eu). The funders had no role in study design, data collection and analysis, decision to publish or preparation of the manuscript.

\section{References}

1. Paupy C, Delatte H, Bagny L, Corbel V, Fontenille D. Aedes albopictus, an arbovirus vector: from the darkness to the light. Microbes Infect. 2009;11(14-15):1177-85. http://dx.doi. org/10.1016/j.micinf.2009.05.005

2. Medlock JM, Hansford KM, Schaffner F, Versteirt V, Hendrickx $\mathrm{G}$, Zeller $\mathrm{H}$, et al. A review of the invasive mosquitoes in Europe: ecology, public health risks, and control options. Vector Borne Zoonotic Dis. 2012;12(6):435-47. http://dx.doi. org/10.1089/vbz.2011.0814

3. Hawley WA. The biology of Aedes albopictus. J Am Mosq Control Assoc Suppl. 1988;1:1-39.

4. Lounibos LP. Invasions by insect vectors of human diseases. Annu Rev Entomol. 2002;47:233-66. http://dx.doi.org/10.1146/ annurev.ento.47.091201.145206

5. Scolte E-J, Schaffner F. Waiting for the tiger: establishment and spread of the Aedes albopictus mosquito in Europe. In: Takken W, Knols BG, editors. Emerging pests and vector-borne diseases in Europe. Volume 1. Wageningen: Wageningen Academic Publishers; 2007. p. 241-60. Available from: http:// www.wageningenacademic.com/_clientFiles/download/ecvd01-e.pdf

6. Gratz NG. Critical review of the vector status of Aedes albopictus. Med Vet Entomol. 2004;18(3):215-27. http://dx.doi. org/10.1111/j.0269-283X.2004.00513.X

7. Rezza G, Nicoletti L, Angelini R, Romi R, Finarelli AC, Panning $M$, et al. Infection with chikungunya virus in Italy: an outbreak in a temperate region. Lancet. 2007;370(9602):1840-6. http:// dx.doi.org/10.1016/S0140-6736(07)61779-6

8. Grandadam $M$, Caro V, Plumet $S$, Thiberge J-M, Souarès $Y$, Failloux $A B$, et al. Chikungunya virus, southeastern France. Emerg Infect Dis. 2011;17(5):910-3. http://dx.doi.org/10.3201/ eid1705.101873

9. La Ruche G, Souarès Y, Armengaud A, Peloux-Petiot F, Delaunay $P$, Desprès $P$, et al. First two autochthonous dengue virus infections in metropolitan France, September 2010. Euro Surveill. 2010;15(39):pii=19676. Available from: http://www. eurosurveillance.org/ViewArticle.aspx?Articleld=19676

10. Schmidt-Chanasit J, Haditsch M, Schöneberg I, Günter S, Stark $\mathrm{K}$, Frank $\mathrm{C}$. Dengue virus infection in a traveller returning from Croatia to Germany. Euro Surveill. 2010;15(40):pii=19677. Available from: http://www.eurosurveillance.org/ViewArticle. aspx?Articleld=19677

11. Gjenero-Margan I, Aleraj B, Krajcar D, Lesnikar V, Klobučar A, Pem-Novosel I, et al. Autochthonous dengue fever in Croatia, August-September 2010. Euro Surveill. 2011;16(9):pii=19805. Available from: http://www.eurosurveillance.org/ViewArticle. aspx?Articleld $=19805$

12. Sousa CA, Clairouin M, Seixas G, Viveiros B, Novo MT, Silva AC, et al. Ongoing outbreak of dengue type 1 in the autonomous Region of Madeira, Portugal: preliminary report. Euro Surveill. 2012;17(49):pii=20333. Available from: http:// www.eurosurveillance.org/ViewArticle.aspx?Articleld $=20333$

13. Mitchell CJ. Geographic spread of Aedes albopictus and potential for involvement in arbovirus cycles in the Mediterranean Basin. J Vector Ecol. 1995;20:44-58.

14. Medlock JM, Avenell D, Barrass I, Leach S. Analysis of the potential for survival and seasonal activity of Aedes albopictus (Diptera: Culicidae) in the United Kingdom. J Vector Ecol. 2006;31(2):292-304. http://dx.doi. org/10.3376/1081-1710(2006)31[292:AOTPFS]2.0.CO;2

15. European Centre for Disease Prevention and Control (ECDC). The climatic suitability for dengue transmission in continental Europe. Stockholm: ECDC; 2012. Available from: http:// 
ecdc.europa.eu/en/publications/Publications/TER-Climaticsuitablility-dengue.pdf

16. European Centre for Disease Prevention and Control (ECDC). Development of Aedes albopictus risk maps; 2009. Available from: http://ecdc.europa.eu/en/publications/ Publications/0905_TER_Development_of_Aedes_Albopictus Risk_Maps.pdf

17. Fischer D, Thomas SM, Niemitz F, Reineking B, Beierkuhnlein C. Projection of climatic suitability for Aedes albopictus Skuse (Culicidae) in Europe under climate change conditions. Glob Planet Change. 2011;78(1-2):54-64. http://dx.doi. org/10.1016/j.gloplacha.2011.05.008

18. Roiz D, Neteler M, Castellani C, Arnoldi D, Rizzoli A. Climatic factors driving invasion of the tiger mosquito (Aedes albopictus) into new areas of Trentino, northern Italy. PLoS One. 2011;6(4):e14800. http://dx.doi.org/10.1371/journal. pone. 0014800

19. Caminade C, Medlock JM, Ducheyne E, Mclntyre KM, Leach S, Baylis M, et al. Suitability of European climate for the Asian tiger mosquito Aedes albopictus: recent trends and future scenarios. J R Soc Interface. 2012;9(75):2708-17. http://dx.doi. org/10.1098/rsif.2012.0138

20. Kobayashi M, Nihei N, Kurihara T. Analysis of northern distribution of Aedes albopictus in Japan by geographical information systems. J Med Entomol. 2002;39(1):4-11. http:// dx.doi.org/10.1603/0022-2585-39.1.4

21. Morin X, Thuiller W. Comparing niche- and process-based models to reduce prediction uncertainty in species range shifts under climate change. Ecology. 2009;90(5):1301-13. http:// dx.doi.org/10.1890/08-0134.1

22. Dormann CF, Schymanski SJ, Cabral J, Chuine I, Graham C, Hartig F, et al. Correlation and process in species distribution models: bridging a dichotomy. J Biogeogr. 2012;39(12):2119-31. http://dx.doi.org/10.1111/j.1365-2699.2011.02659.x

23. Elith J, Graham CH, Anderson RP, Dudík M, Ferrier S Guisan A, et al. Novel methods improve predictions of species' distributions from occurrence data. Ecography. 2006;29(2):129-51. http://dx.doi. org/10.1111/j.2006.0906-7590.04596.x

24. Benedict MQ, Levine RS, Hawley WA, Lounibos P. Spread of the tiger: global risk of invasion by the mosquito Aedes albopictus. Vector Borne Zoonotic Dis. 2007;7(1):76-85. http://dx.doi. org/10.1089/vbz.2006.0562

25. Medley KA. Niche shifts during the global invasion of the Asian tiger mosquito, Aedes albopictus Skuse (Culicidae), revealed by reciprocal distribution models. Glob Ecol Biogeogr. 2010;19(1):122-33. http://dx.doi. org/10.1111/j.1466-8238.2009.00497.x

26. Intergovernmental Panel on Climate Change (IPCC). IPCC special report. Emissions scenarios. Summary for policymakers. Geneva: IPCC; 2000 . [Accessed 3 Mar 2009]. Available from: http://www.ipcc.ch/pdf/special-reports/spm/ sres-en.pdf

27. Euro-Aegis. VBORNET - European Network for Arthropod Vector Surveillance for Human Public Health. [Accessed 2 Oct 2012]. Available from: http://www.vbornet.eu/

28. Phillips SJ, Anderson RP, Schapire RE. Maximum entropy modeling of species geographic distributions. Ecol Model. 2006;190(3-4):231-59. http://dx.doi.org/10.1016/j. ecolmodel.2005.03.026

29. Elith J, Philips SJ, Hastie T, Dudík M, Chee YE, Yates CJ. A statistical explanation of MaxEnt for ecologists. Divers Distrib. 2011;17:43-57. http://dx.doi. org/10.1111/j.1472-4642.2010.00725.x

30. Honogh V, Hoen AG, Aenishaenslin C, Waaub JP, Bélanger D, Michel $P$, et al. Spatially explicit multi-criteria decision analysis for managing vector-borne diseases. Int J Health Geogr. 2011;10:70. http://dx.doi.org/10.1186/1476-072X-10-70

31. Déqué $M$, Somot $S$, Sanchez-Gomez E, Goodess CM, Jacob D, Lenderink G, et al. The spread amongst ENSEMBLES regional scenarios: regional climate models, driving general circulation models and interannual variability. Clim Dyn. 2012;38:951-64 http://dx.doi.org/10.1007/s00382-011-1053-x

32. Hijmans RJ, Camerion SE, Parra JL, Jones PG, Jarvis A. Very high resolution interpolated climate surfaces for global land areas. Int J Climatol. 2005;25(15):1965-78. http://dx.doi.org/10.1002/ joc. 1276

33. Jacob D, Podzun R. Global warming below $2{ }^{\circ} \mathrm{C}$ relative to preindustrial level: how might climate look like in Europe? Nov Act LC. 2010;112(384):71-6.

34. Fitzpatrick MC, Hargrove WW. The projections of species distribution models and the problem of non-analog climate. Biodivers Conserv. 2009;18:2255-61. http://dx.doi. org/10.1007/s10531-009-9584-8
35. Webber BL, Le Maitre DC, Kriticos DJ. Comment on "Climatic niche shifts are rare among terrestrial plant invaders". Science. 2012;338(6104):193. http://dx.doi.org/10.1126/ science.1225980 http://dx.doi.org/10.1126/science.1226051

36. Elith J, Kearney M, Phillips S. The art of modelling range shifting species. Methods Ecol Evol. 2010;1(4):330-42. http:// dx.doi.org/10.1111/j.2041-210X.2010.00036.x

37. Walther GR, Roques A, Hulme PE, Sykes MT, Pysek P, Kühn I, et al. Alien species in a warmer world : risks and opportunities. Trends Ecol Evol. 2009;24:686-93. http://dx.doi.org/10.1016/j. tree.2009.06.008

38. Thomas SM, Beierkuhnlein C. Predicting ectotherm disease vector spread-benefits from multidisciplinary approaches and directions forward. Naturwissenschaften. 2013;100(5):395-405. http://dx.doi.org/10.1007/s00114-013-1039-0

39. European Centre for Disease Prevention and Control (ECDC). Guidelines for the surveillance of invasive mosquitoes in Europe. Stockholm: ECDC; 2012. Available from: http://ecdc. europa.eu/en/publications/Publications/TER-Mosquitosurveillance-guidelines.pdf

40. Knudsen AB. Global distribution and continuing spread of Aedes albopictus. Parassitologia. 1995;37(2-3):91-7.

41. Tatem AJ, Hay SI, Rogers DJ. Global traffic and disease vector dispersal. Proc. Natl Acad Sci U S A. 2006;103(16):6242-7. http://dx.doi.org/10.1073/pnas.0508391103

42. Scholte EJ, Dijkstra E, Blok H, De Vries A, Takken W, Hofhuis A, et al. Accidental importation of the mosquito Aedes albopictus into the Netherlands: a survey of mosquito distribution and the presence of dengue virus. Med Vet Entomol. 2008;22(4):352-8. http://dx.doi.org/10.1111/j.1365-2915.2008.00763.x

43. Scholte EJ, Dik M, Ibaňez Justicia A, Den Hartog W, Schoelitsz $B$, Brooks M. Findings and control of two invasive exotic mosquito species, Aedes albopictus and Ae. atropalpus (Diptera: Culicidae) in the Netherlands, 2011. Euro Mosq Bull. 2012;30:1-14.

44. Fischer D, Moeller P, Thomas SM, Naucke TJ, Beierkuhnlein C. Combining climatic projections and dispersal ability: a method for estimating the responses of sandfly vectors species to climate change. PLoS Neglect Trop Dis. 2011;5:e1407. http:// dx.doi.org/10.1371/journal.pntd.0001407

45. Pluskota B, Storch V, Braunbeck T, Beck M, Becker N. First record of Stegomyia albopicta (Skuse) (Diptera: Culicidae) in Germany. Euro Mosq Bull. 2008;26:1-5.

46. Werner D, Kronefeld M, Schaffner F, Kampen H. Two invasive mosquito species, Aedes albopictus and Aedes japonicus japonicus, trapped in south-west Germany, July to August 2011 Euro Surveill. 2012;17(4):pii=20067. Available from: http:// www.eurosurveillance.org/ViewArticle.aspx?Articleld =20067

47. Šebesta O, Rudolf I, Betášová L, Peško J, Hubálek Z. An invasive mosquito species Aedes albopictus found in the Czech Republic, 2012. Euro Surveill. 2012;17(43):pii=20301. Available from: http://www.eurosurveillance.org/ViewArticle. aspx?Articleld $=20301$

48. Estrada-Franco J, Caraig GB. Biology, disease relationship, and control of Aedes albopictus. Pan American Health Organization (PAHO) Technical Paper. Washington DC: PAHO; 1995.

49. Juliano SA, Lounibos LP. Ecology of invasive mosquitoes: effects on resident species and on human health. Ecol Lett. 2005;8(5):558-74. http://dx.doi. org/10.1111/j.1461-0248.2005.00755.x

50. Marini F, Caputo B, Pombi M, Tarsitani G, della Torre A. Study of Aedes albopictus dispersal in Rome, Italy, using sticky traps in mark-release-recapture experiments. Med Vet Entomol. 2010;24(4):361-8. http://dx.doi. org/10.1111/j.1365-2915.2010.00898.x

51. Neteler M, Roiz D, Rocchini D, Castellani C, Rizzoli A. Terra and Aqua satellites track tiger mosquito invasion: modelling the potential distribution of Aedes albopictus in north eastern Italy. Int J Health Geogr. 2011;10:49. http://dx.doi. org/10.1186/1476-072X-10-49

52. Neteler M, Metz M, Rocchini D, Rizzoli A, Flacio E, Engeler $\mathrm{L}$, et al. Is Switzerland suitable for the invasion of Aedes albopictus? PLoS One. 2013;8(12):e82090. http://dx.doi. org/10.1371/journal.pone.0082090 http://dx.doi.org/10.1371/ annotation/d1d46d6e-8152-4eab-8df9-7f2e5d14f391

53. Urbanski JM, Benoit JB, Michaud MR, Denlinger DL, Armbruster $P$. The molecular physiology of increased egg desiccation resistance during diapause in the invasive mosquito, Aedes albopictus. Proc Biol Sci. 2010;277(1694):2683-92. http:// dx.doi.org/10.1098/rspb.2010.0362

54. Romi R, Severin F, Toma L. Cold acclimation and overwintering of female Aedes albopictus in Roma. J Am Mosq Control Assoc. 2006;22(1):149-51. http://dx.doi.org/10.2987/8756-971X(2006 )22[149:CAAOOF]2.0.CO;2 
55. Thomas SM, Obermayr U, Fischer D, Kreyling J, Beierkuhnlein C. Low-temperature threshold for egg survival of a postdiapause and non-diapause European aedine strain, Aedes albopictus (Diptera: Culicidae). Parasite Vectors. 2012;5:100. http://dx.doi.org/10.1186/1756-3305-5-100

56. Moss RH, Edmonds JA, Hibbard KA, Manning MR, Rose SK, van Vuuren DP, et al. The next generation of scenarios for climate change research and assessment. Nature. 2010;463(7282):74756. http://dx.doi.org/10.1038/natureo8823

57. Taylor KE, Stouffer RJ, Meehl GA. An overview of CMIP5 and the experiment design. Bull Amer Meteorol Soc. 2012;93(4):48598. http://dx.doi.org/10.1175/BAMS-D-11-00094.1

58. Field CB, Barros V, Stocker TF, Qin D, Dokken DJ, Ebi KL, et al. editors. Managing the risks of extreme events and disasters to advance climate change adaptation. A Special Report of Working Groups I and II of the Intergovernmental Panel on Climate Change. Cambridge, UK, and New York, NY: Cambridge University Press; 2012. Available from: http://www.ipcc-wg2. gov/SREX/images/uploads/SREX-All_FINAL.pdf

59. Thomas SM, Fischer D, Fleischmann S, Bittner T, Beierkuhnlein C. Risk assessment of dengue virus amplification in Europe based on spatio-temporal high resolution climate change projections. Erdkunde. 2011;65(2):137-50. http://dx.doi. org/10.3112/erdkunde.2011.02.03

6o. Tjaden NB, Thomas SM, Fischer D, Beierkuhnlein C. Extrinsic incubation period of dengue: knowledge, backlog, and applications of temperature-dependence. PLoS Neglect Trop Dis. 2013;7(6):e2207. http://dx.doi.org/10.1371/journal. pntd.0002207

61. Tilston N, Skelly C, Weinstein P. Pan-European Chikungunya surveillance: designing risk stratified surveillance zones. Int J Health Geogr. 2009;8:61. http://dx.doi. org/10.1186/1476-072X-8-61

62. Fischer D, Thomas SM, Suk JE, Sudre B, Hess A, Tiaden NB, et al. Climate change effects on Chikungunya transmission in Europe: geospatial analysis of vector's climatic suitability and virus' temperature requirements. Int J Health Geogr. 2013;12:51. http://dx.doi.org/10.1186/1476-072X-12-51

63. Poretta D, Mastrantonio V, Bellini R, Somboon P, Urbanelli S. Glacial history of a modern invader: phylogeography and species distribution modelling of the Asian tiger mosquito Aedes albopictus. PLoS One. 2012;7:e44515. http://dx.doi. org/10.1371/journal.pone.0044515

64. Erickson RA, Hayhoe K, Presley SM, Allen LJ, Long KR, Cox SB. Potential impacts of climate change on the ecology of dengue and its mosquito vector the Asian tiger mosquito (Aedes albopictus). Environ Res Lett. 2012;7:034003. http://dx.doi. org/10.1088/1748-9326/7/3/034003

65. Suk JE, Semenza JC. Future infectious disease threats to Europe. Am J Public Health. 2011;101(11):2068-79. http:// dx.doi.org/10.2105/AJPH.2011.300181

66. Lindgren E, Andersson Y, Suk JE, Sudre B, Semenza JC. Public Health. Monitoring EU emerging infectious disease risk due to climate change. Science. 2012;336(6080):418-9. http://dx.doi. org/10.1126/science.1215735

67. Semenza JC, Suk JE, Estevez V, Ebi KL, Lindgren E. Mapping climate change vulnerabilities to infectious diseases in Europe. Environ Health Persp. 2012;120(3):385-92. http://dx.doi. org/10.1289/ehp.1103805

68. Semenza JC, Sudre B, Oni T, Suk JE, Giesecke J. Linking environmental drivers to infectious diseases: the European environment and epidemiology network. PLoS Negl Trop Dis. 2013;7(7):e2323. http://dx.doi.org/10.1371/journal. pntd.0002323

69. European Centre for Disease Prevention and Control (ECDC) Environmental risk mapping: Aedes albopictus in Europe. Stockholm: ECDC; 2013. Available from: http://www.ecdc. europa.eu/en/publications/Publications/climate-changeenvironmental-risk-mapping-aedes.pdf

70. Rogers DJ, Suk JE, Semenza JC. Using global maps to predict the risk of dengue in Europe. Acta Trop. 2014;129:1-14. http:// dx.doi.org/10.1016/j.actatropica.2013.08.008 